\title{
Compensation at Market Value for Land Reform? A Critical Assessment of the MalaMala Judgment's Approach to Compensation for Expropriation in South Africa
}

\author{
Johan Lorenzen ${ }^{1}$
}

\begin{abstract}
As the State seeks to move away from the 'willing buyer, willing seller' approach to determining compensation for expropriations in the context of land reform, the Property Valuation Act has been passed. It proposes determining compensation for expropriation with regard to all factors listed in section 25(3) of the Constitution on the assumption that this will de-emphasise market value in favour of a more holistic approach. This assumption is undercut by the recent MalaMala judgment in the Land Claims Court, where a consideration of the section 25(3) factors found no reason to deviate from market value.

This paper critically assesses the MalaMala judgment. It suggests that the judgment over-emphasised market value in its approach, both in its approach to the nature of compensation and its application of the section 25(3) factors. It argues that such an approach neglects the varied understandings of the nature of compensation in comparative international law, ignores the unique language of section 25(3), and elides the historical context of land acquisition and the consequent value of land reform. The paper therefore argues that the judgment should not impede the implementation of the Property Valuation Act.

"This Act therefore, seems to us like a one-edged knife - it cuts a big piece off the native and is very gentle with the European. The white man is told: 'If the natives do not carry out the landlord's wishes, chase them off the farm' but the natives are not told where to go to." 2
\end{abstract}

Reverend Mtinkuli

1 Candidate Attorney, Richard Spoor Inc, Attorneys. This paper was written under the auspices of the LandLawWatch project at the University of Cape Town. The views and opinions expressed here are the author's own and should not be attributed to the LandLawWatch project or the University of Cape Town. E-Mail: johan@richardspoorinc.co.za.

2 Evidence given in 1916 to the Beaumont Commission on the impact of the Natives Land Act in Colin Bundy Land, Law and Power, in Murray \& O'Regan (eds) No Place to Rest: Forced Removals and the Law in South Africa, Oxford 1990, 3. 


\section{Introduction}

Distortions in land ownership patterns along racial lines are the direct result of a long history of colonialism and apartheid. ${ }^{3}$ While in many respects it merely codified existing unjust land ownership patterns, it is the 1913 Natives Land $\mathrm{Act}^{4}$ that 'provided the statutory basis of territorial segregation' by formalising the prohibition on black land ownership outside 'native reserves'. ${ }^{5}$ These reserves initially covered around $8 \%$ of South Africa's total land area and increased to $13 \%$ in $1936 .{ }^{6}$ Black South Africans who owned land outside of these designated areas were subject to forced removals with little or no compensation. ${ }^{7}$ The Act was merely the most prominent of a network of discriminatory laws and practices around land ownership. ${ }^{8}$ By the time of the first democratic elections in 1994, an estimated 3,5 million South Africans had been displaced by apartheid land law. ${ }^{9}$

Under the democratic dispensation, the new Constitution entrenched the right to restitution for persons dispossessed as a result of racially discriminatory laws. ${ }^{10}$ The 1997 White Paper on Land Policy sought to give effect to these constitutional provisions, setting out three key elements of the land reform programme: restitution, redistribution and tenure reform. ${ }^{11}$ The African National Congress (ANC)-led government displayed a determination to undo the legacy of distorted land ownership, targeting the transfer of $30 \%$ of commercial agricultural land (25 million hectares) by 1999 in its Reconstruction and Development Plan. ${ }^{12}$

Twenty years into South Africa's democratic dispensation, there is a palpable, growing frustration with the slow pace of land reform. ${ }^{13}$ The target of transferring 25 million hectares of commercial agricultural land by 2015 , itself significantly more modest than the Reconstruction and Development Plan target, is far from reached. According to the Department of Rural Development and Land Reform (DRDLR), only around seven million hectares (25\% of the target) had been transferred as of November $2013 .{ }^{14}$ As pressure in-

3 Bundy, note $1,7$.

427 of 1913.

5 Bundy, note $1,7$.

6 Bundy, note 1, 7; Native Trust and Land Act 18 of 1936.

7 Laurine Platzky \& Cheryl Walker, The Surplus People, Johannesburg 1985, 8-9.

8 Department of Land Affairs and Others v Goedgelegen Tropical Fruits (Pty) Ltd 2007 (6) SA 199 (CC) [56]; Geoff Budlender, Unravelling Rights, in de Klerk (ed), A Harvest of Discontent: The Land Question in South Africa, Cape Town 1991, 116.

9 Platzky \& Walker, note 6, 8-9.

10 Constitution of the Republic of South Africa, 1996 s 25(7).

11 DRDLR, White Paper on Land Policy, 1997, 4.

$12 A N C$, The Reconstruction and Development Programme, Johannesburg 1994, s 2.4.14.

13 Ben Cousins \& Ruth Hall, Rural Land Tenure, Cousins, Dugard, Langford \& Madlingozi (eds), Socio-Economic Rights in South Africa, Cambridge 2013, 158-159.

14 DRDLR, note $10,10$. 
creases on the state to quicken the pace of land restitution and redistribution, it has identified the high prices paid to land owners under the market-based, consent-oriented compensation model as a barrier to meeting its goals. ${ }^{15}$

After acknowledging the desire for an accelerated land reform process in his 2013 State of the Nation Address, President Zuma committed to shifting from the "willing buyer, willing seller" principle, in which landowners only transfer their land if offered sufficiently high compensation to render them willing sellers, to an approach based on just and equitable compensation. ${ }^{16}$ To give effect to this shift, the DRDLR has proposed a new land reform model that de-emphasises the consent of current owners and includes a greater willingness to expropriate land. ${ }^{17}$

To determine the compensation payable, the DRDLR submitted the Property Valuation Bill, which was signed into law by the President as the Property Valuation Act on 30 June 2014 and will come into effect on a date to be proclaimed. ${ }^{18}$ The Act will see the establishment of the office of a Valuer-General responsible for conducting valuations on all property identified for the purposes of land reform. ${ }^{19}$ The value of property, as defined in the Act, is determined with reference to the test for compensation payable upon expropriation set out in section 25(3) of the Constitution (hereafter the "section 25(3) factors"). ${ }^{20}$ Instead of determining value exclusively by market value, the section 25(3) factors consider market value as only one of a range of factors considered in balancing the public interest and the interest of those affected. ${ }^{21}$ The Act appears to assume that valuation based on section 25(3) of the Constitution will de-emphasise market value for a more holistic, historically informed determination of compensation. In President Zuma's words in his 2015 State of the Nation address, "[o]nce implemented the [Property Valuation Act] will stop the reliance on the Willing Buyer-Willing Seller method in respect of land acquisition by the state."22

15 DRDLR, Green Paper on Land Reform, 2011, 5.

16 The Presidency, State of the Nation Address 2013, http://www.thepresidency.gov.za/pebble.asp?re lid=14960 (accessed 11 June 2014).

17 DRDLR, note 10.

18 Property Valuation Act 17 of 2014.

19 Property Valuation Act 17 of 2014, s 1.

20 "The amount of the compensation and the time and manner of payment must be just and equitable, reflecting an equitable balance between the public interest and the interests of those affected, having regard to all relevant circumstances, including

a. the current use of the property;

b. the history of the acquisition and use of the property;

c. the market value of the property;

d. the extent of direct state investment and subsidy in the acquisition and beneficial capital improvement of the property; and

e. the purpose of the expropriation.".

21 Property Valuation Act 17 of 2014, s 1.

22 The Presidency, State of the Nation Address 2015, http://www.thepresidency.gov.za/pebble.asp?re lid $=14960$ (accessed 15 February 2015). 
On the one hand, the Property Valuation Act may shift policy in the context of land redistribution as the Expropriation Act currently governs expropriations for redistribution. The Expropriation Act, enacted prior to 1994, only provides for market-based compensation for expropriations. ${ }^{23}$ On the other hand, section $42 \mathrm{E}(3)$ of the Restitution of Land Rights Act (hereafter "the Restitution Act") already establishes that valuation for expropriations in the context of land restitution should be based on the full range of factors listed in section 25(3) of the Constitution. The Property Valuation Act will therefore not change the statutory framework in terms of factors to consider in determining value in the context of expropriation for restitution purposes.

The factors for valuation listed in the Act have already been tested and applied by the judiciary in cases related to expropriation. As courts must agree to compensation payable where the parties disagree, any case law on the application of section 25(3) will have significant implications for the implementation of the Act. It is therefore necessary to consider the approach to these factors taken by the courts to ascertain how this body of case law will impact the implementation of the Property Valuation Act in the context of land restitution, if at all. Should the case law reject the assumption that the section 25(3) factors allows for a significant departure from market value, it is possible that expropriations made in terms of this assumption may be found unconstitutional by the courts. A string of cases have considered section 25(3), but many of the cases stand to be distinguished from the context in which the Property Valuation Act will operate as they are not expropriations for the purpose of land reform. ${ }^{24}$

The recent Land Claims Court judgment in Mhlanganisweni Community v Minister of Rural Development and Land Reform ${ }^{25}$ (hereafter "MalaMala") is the first case to consider compensation for a land reform expropriation of a land owner who acquired the expropriated property before 1994. It purports to reflect the jurisprudence around the application of the section 25(3) factors and is therefore an important starting point for considering the potential impact of case law on the Property Valuation Act. The judgment of Gildenhuys J, which considered all of the section 25(3) factors in determining compensation for a restitution claim, concluded that none of the factors "require compensation to be determined at significantly less than market value." 26 This judgment is particularly significant given the prominent position of Gildenhuys $\mathrm{J}$ in developing and analysing South African law around expropriation. His Onteieningsreg ${ }^{27}$ has been described by Van der Walt as 'the most im-

23 Expropriation Act 63 of 1975, s 12.

24 These cases are named and distinguished in section 3.2 below.

25 [2012] JOL 28899 (LCC).

26 [77].

27 Antonie Gildenhuys, Onteieningsreg, (2nd ed) 2001. 
portant post-constitutional source' on the compensation requirements. ${ }^{28}$ His Land Claims Court judgments have been cited with approval by the Constitutional Court. ${ }^{29}$

The judgment in the MalaMala case appears to undermine the assumption that the Property Valuation Act will have a significant impact on the valuation of properties identified for land reform. Given the serious implications this outcome would have on the land reform project as a whole, this research paper seeks to analyse the MalaMala judgment to determine whether the judgment's approach to compensation must be followed by the Valuer-General in implementing the Property Valuation Act. To do this, the paper critically assesses the MalaMala judgment's understanding of how market value interacts with other factors in determining compensation as laid out in section 25(3) in the context of land restitution.

The paper posits that the MalaMala judgment's was misdirected in emphasising market value over the other factors listed in section 25(3) of the Constitution. It argues that such an approach neglects the varied understandings of the nature of compensation in comparative international law, ignores the unique language of section 25(3), and elides the historical context of land acquisition and the consequent value of land reform. While the judgment is somewhat attuned to the plight of those who suffered from apartheid's forced removals, this elision is particularly pronounced in the narrow approach with which the judgment considers the advances obtained by apartheid's beneficiaries. The paper therefore argues that the judgment should not impede the implementation of the Property Valuation Act.

\section{The MalaMala Judgment}

The recent Land Claims Court judgment in Mhlanganisweni Community v Minister of Rural Development and Land Reform ${ }^{30}$ does not bode well for the assumption that applying the section 25(3) factors will produce valuations below market value. The judgment of Gildenhuys J, which considered all of the section 25(3) factors, ${ }^{31}$ states that a section 25(3) inquiry entails a two-phase approach. The first phase determines the market value. ${ }^{32}$ The second phase considers whether any of the other section 25(3) factors affect the market value. ${ }^{33}$ In applying this approach, Gildenhuys $\mathrm{J}$ concludes that none of the factors "require compensation to be determined at significantly less than market value." 34 In reaching this conclusion, Gildenhuys J clearly elevates market value as the primary consideration in applying section 25(3) to expropriations in the context of land restitution. In doing this, he

28 Andries Van der Walt, Constitutional Property Law, Cape Town 2005, 504.

29 Du Toit v Minister of Transport 2006 (1) SA 297 (CC) [35].

30 [2012] JOL 28899 (LCC).

31 [47]-[87].

32 [54]-[59].

33 [60]-[73].

34 [77]. 
relegates the other factors as secondary and applicable only in extraordinary circumstances. To consider the judgment it is important to outline the facts on which the judgment was reached briefly.

\subsection{Facts of MalaMala}

While the history and facts were contested, it was common cause that a significant number of black residents of the plots of land collectively referred to as the MalaMala land in the judgment ${ }^{35}$ were forcibly removed in the $1950 \mathrm{~s}^{36}$ The current owners acquired the properties between 1964 and 1982. ${ }^{37}$ During the initial land restitution claims window, several parties lodged claims on the MalaMala land. ${ }^{38}$ By agreement between these parties and the Regional Land Claims Commissioner of Mpumalanga, the claims were merged into a single claim under the name of the Mhlangisweni community. ${ }^{39}$ Notably, the land claimed contains the MalaMala Game Reserve, a world-renowned eco-tourism site. ${ }^{40}$

After settlement negotiations 'came to nought', the claim was referred to the Land Claims Court in 2009. ${ }^{41}$ While the Regional Land Claims Commissioner recommended that the land should be restored to the claimants, the Commissioner also submitted that if the amount of compensation was determined to be higher than R 30000 per hectare it would not be feasible to restore the land to the claimants. ${ }^{42}$ While the land owners accepted the validity of the claim, they "submitted that if the MalaMala land was to be expropriated, the compensation payable to them would exceed Rand (R) 30000 per hectare."43

The parties therefore agreed to a separation of issues to determine whether restoration was feasible in terms of the Restitution of Land Rights Act first. ${ }^{44}$ The Act provides that the Land Claims Court shall, in considering whether a claimant should be awarded restoration of the land, consider "the feasibility of such a claim." 45 It should be noted that where a valid claim is found to be unfeasible, claimants are entitled to alternative forms of equitable redress such as compensation. ${ }^{46}$ While the judgment considered several factors in determin-

$35[2]$.

36 [42].

37 [43].

38 [1].

$39[1]$.

40 [46].

$41[5]$.

$42[6]$.

43 [11]-[12].

44 [14].

45 Restitution of Land Rights Act 22 of 1994, s 33(cA).

46 Constitution of the Republic of South Africa, 1996, s 25(7). 
ing whether restitution was feasible, ${ }^{47}$ an important factor in determining feasibility was held to be an estimate of the amount of compensation payable if restoration were to be ordered. ${ }^{48}$ The calculation of compensation was coupled with the question of whether the state could fairly be asked to pay the compensation owed. ${ }^{49}$

\subsection{Nature of Compensation}

In determining compensation payable, Gildenhuys $\mathrm{J}$ begins by setting out the requirements of section 25(3) of the Constitution. ${ }^{50}$ For convenience, section 25(3) states that compensation "must be just and equitable, reflecting an equitable balance between the public interest and the interests of those affected, having regard to all relevant circumstances, including (a) the current use of the property; (b) the history of the acquisition and use of the property; (c) the market value of the property; (d) the extent of direct state investment and subsidy in the acquisition and beneficial capital improvement of the property; and (e) the purpose of the expropriation." 51

To interpret and apply section 25(3), Gildenhuys J uses South African and international sources of law and academic opinion to ascertain the nature of compensation. He begins by holding that "[c]ompensation, to be just and equitable, must recompense." 52 He then notes Southwood's statement that in terms of the dictionary meaning 'compensate' as a word "has a strong connotation of equality between what is given and what was lost." 53 He cites with approval Harms ADP's (as he then was) statement in Haakdoornbult Boerdery CC \& Others $v$ Mphela \& Others (hereafter "Mphela") that " $[\mathrm{t}]$ he purpose of giving fair compensation is to put the dispossessed, insofar as money can do it, in the same position as if the land had not been taken." ${ }^{54} \mathrm{He}$ goes on to state that "[t] he purpose of compensation is to place in the hands of the expropriated owner the full money equivalent of the expropriated property." ${ }^{\circ 5} \mathrm{He}$ substantiates this statement with a dictum from the Australian High Court's decision in Nelungaloo Pty Ltd $v$ Commonwealth. ${ }^{56} \mathrm{He}$ also cites the somewhat circular state-

47 Mhlanganisweni Community v Minister of Rural Development and Land Reform \& Others [2012] JOL 28899 (LCC) [79]-[90].

48 [47]; per [49], there was no need to determine the exact amount of compensation as the issue before the court was feasibility and was not an expropriation.

49 [47].

50 [48].

51 Constitution of the Republic of South Africa, 1996.

52 Mhlanganisweni Community v Minister of Rural Development and Land Reform \& Others [2012] JOL 28899 (LCC) [50].

53 Michael Southwood, Compulsory Acquisition of Rights: the Constitutions, Cape Town 2000, 25.

54 Haakdoornbult Boerdery CC \& Others v Mphela \& Others 2007 (5) SA 596 (SCA) [48].

55 Mhlanganisweni Community v Minister of Rural Development and Land Reform \& Others [2012] JOL 28899 (LCC) [51].

56 (1948) 75 CLR 495571. 
ment of the British House of Lords in Birmingham City Corporation v West Midland Baptist (Trust) Association (Incorporated) that "[t]he word 'compensation' would be a mockery if what was paid was something that did not compensate." 57 He notes that this dictum was cited with approval by the Witwatersrand Local Division Sandton Town Council v Erf 89 Sandown Extension 2 (Pty) Ltd in 1988. ${ }^{58}$

\subsection{Market Value}

Following this discussion of the nature of compensation, Gildenhuys $\mathrm{J}$ states that an "important circumstance to take into account when deciding just and equitable compensation is the market value of the property." 59 He then lays out the two-stage approach approved of by the Constitutional Court in Du Toit v Minister of Transport (hereafter "Du Toit"). ${ }^{60}$ The approach entails starting with the consideration of market value and then determining whether this amount is just and equitable by considering the other factors in section 25(3). ${ }^{61}$ He notes that the Constitutional Court had found the two-stage approach to be the most practical in Du Toit but had emphasised that the two-stage approach may not be appropriate in every instance. ${ }^{62}$ Noting that several other cases have followed the two-stage approach, he stated that he will also follow the approach and begin by considering the market value of the property. ${ }^{63}$

To ascertain the market value of the MalaMala property, Gildenhuys J relies on the evidence of valuers presented by the parties. With the state disregarding the evidence of its valuer, ${ }^{64}$ Gildenhuys $\mathrm{J}$ considers the valuations submitted by the claimants and the land owners. ${ }^{65}$ He casts aspersions upon the valuation of the claimants, which valued the land at R 55000 to R 65000 per hectare, as it relied on a price escalation rate to earlier comparable sales. ${ }^{66} \mathrm{He}$ presents the valuation of the land owners, based on "extensive analysis of comparable sales" and valuing the property at R 72000 to R 87000 , more favourably (despite the claimants having noted that the same valuer had valued an adjacent property at $\mathrm{R}$ 17000 while valuing for the state). ${ }^{67}$ As all parties were agreed that compensation above $\mathrm{R}$

57 [1970] AC 874.

581986 (4) SA $576(\mathrm{~W})$ 579I.

59 [52].

602006 (1) SA 297 (CC).

61 [52].

62 Mhlanganisweni Community v Minister of Rural Development and Land Reform \& Others [2012] JOL 28899 (LCC) [53].

63 [53].

$64[55]$.

$65[56]-[59]$.

66 [56].

67 [57]. 
30000 per hectare would not be feasible he did not reach a final conclusion on the market value but accepted that it was at least the R 55000 per hectare asserted by the claimants. ${ }^{68}$

\section{4 "The Other Relevant Circumstances"}

Moving on to what the he refers to as "the other relevant circumstances," 69 Gildenhuys J briefly notes that the current use of the land is eco-tourism. ${ }^{70} \mathrm{He}$ states that this is relevant and will be considered later. ${ }^{71}$

\subsubsection{History of Acquisition and Use}

On the history of the acquisition of the land, the claimants had argued for a "historic cost of acquisition model" whereby the cost of the land owner's acquisition would be calculated forward using various investment indices. ${ }^{72}$ To the claimants, this model would moderate the distortions of market value and account for the fact that the land was made more affordable and higher value through the specific dispossession and the range of legislative and policy measures that enabled land ownership under the apartheid regime. ${ }^{73}$

Gildenhuys $\mathrm{J}$ rejects the claimants' cost of acquisition model and the argument that such an approach would be acceptable given the wealth accumulated by the land owners. ${ }^{74}$ In doing so he relies on a presentation by the 'Mexican jurist Margadant' to argue that such an approach would be discriminatory to the wealthy. ${ }^{75} \mathrm{He}$ then quotes a presentation by McCall where he argued that " $[\mathrm{t}]$ he burden should not be placed unjustly and disproportionately onto the shoulders of a few, regardless of the historical reasons which may have led to their acquisition of the land." ${ }^{, 76}$ He goes on to consider whether compensation could be reduced based on the racial discrimination of the claimants. ${ }^{77}$ As the dispossessions occurred before the present owners acquired the MalaMala land, he finds that there need not be any reduction in the value of compensation to "atone" for the racially discriminatory dispossession of the claimants. ${ }^{78}$

68 [59].

$69[53]$.

$70[60]$.

$71[60]$.

72 [61], [63].

73 Applicants' heads of argument before the Constitutional Court, http://www.constitutionalcourt.org .za/Archimages/20846.PDF (accessed 14 February 2015), [99]-[101].

74 [61].

$75[62]$.

$76[62]$.

77 [68].

78 [68]. 


\subsection{2 "The Purpose of the Expropriation"}

After this, he turns to the purpose of expropriation factor. ${ }^{79}$ He notes subsection 25(8) of the Constitution's endorsement of land reform ${ }^{80}$ and considers the suggestion that 25(8) of the Constitution could reduce the protections of 25(2-3) regarding compensation. ${ }^{81} \mathrm{He}$ juxtaposes this suggestion with the following quote from Van der Walt: "since the purpose of the expropriation (eg land reform) is already taken into account in justifying the expropriation, it should not be enough to override other factors in determining the amount of compensation." $" 82$

Gildenhuys J then explicitly rejects the relevance of section 25(8), stating, "I see no logical reason why a land owner whose property is expropriated for purposes of land reform, should receive less compensation than a land owner whose property is expropriated for a more mundane purpose, such as a storage dam, a school or a hospital." 83 He again quotes Van der Walt, this time noting Van der Walt's statement that land reform is accepted to be in the public interest worldwide. ${ }^{84} \mathrm{He}$ further states that "[L]and reform in the public interest does not rank superior to any other legitimate purpose for which property may be expropriated, and the determination of compensation must not be different." 85

\subsection{Feasibility and Order}

Gildenhuys J ultimately finds that after considering the section 25(3) factors the amount of compensation would not be less than the lowest estimation of market value (R 55000 per hectare) ${ }^{86}$ In addition to being a strain on state finances, he finds that compensation at this level would constitute overcompensation of the claimants relative to the rights that they possessed before the dispossession. ${ }^{87} \mathrm{He}$ also casts doubts on the viability of the co-operation agreement under which MalaMala would be managed post-restoration. ${ }^{88}$ While noting

79 [71]-[73].

80 "No provision of this section may impede the state from taking legislative and other measures to achieve land, water and related reform, in order to redress the results of past racial discrimination, provided that any departure from the provisions of this section is in accordance with the provisions of section 36 (1).".

81 Mhlanganisweni Community v Minister of Rural Development and Land Reform \& Others [2012] JOL 28899 (LCC) [72].

82 Van der Walt, note 27, 507.

83 Mhlanganisweni Community v Minister of Rural Development and Land Reform \& Others [2012] JOL 28899 (LCC) [72].

84 Van der Walt, The Constitutional Property Clause, 1997 Cape Town, 162.

85 Mhlanganisweni Community v Minister of Rural Development and Land Reform \& Others [2012] JOL 28899 (LCC) [73].

86 [77].

87 [93].

88 [95]. 
that restoration of land is the preferable form of restitution, ${ }^{89}$ Gildenhuys $\mathrm{J}$ concludes by making an order declaring that restoration is not feasible. ${ }^{90}$

\subsection{Implications for the Property Valuation Act}

The MalaMala judgment is a thorough rebuke to the assumption that incorporating all of the section 25(3) factors will shift the calculation of compensation away from market value. It begins by equating compensation with what has been lost. It then suggests that compensation should be calculated with market value in a central position and the other factors considered merely to establish whether this default position should be deviated from. In considering these factors, it finds no logic to the assumption, central to the Property Valuation Act's objectives, that land reform should lead to a detraction from market value. If the judgment is followed, the Property Valuation Act's prospects of enabling the state to compensation land owners for expropriated land at significant rates below market value are not promising.

\section{Analysis of MalaMala}

The approach of Gildenhuys $\mathrm{J}$ in the MalaMala judgment suggests that market value is the starting point for compensation for any expropriation. In considering the other factors listed in section 25(3), the judgment seems to hold that they will only modify market value in extreme circumstances. In considering the judgment in more detail, it is submitted that it reaches these conclusions due to a particular, incomplete view of the nature of compensation. This approach leads to the distortion of the value of the other factors in section 25(3).

\subsection{Nature of Compensation}

Drawing on comparative legal sources, Gildenhuys J's approach to the nature of compensation finds that the purpose of compensation is to place in the hands of the expropriated owner the full money equivalent of the expropriated property. ${ }^{91}$ For ease of reference, this essay uses full money compensation interchangeably with market value as market value is the most reliable benchmark for full money compensation. The claim that market value is the standard for compensation entails two components. The first is that this is a universal position in comparative jurisprudence. The second is that this position is not changed by section 25(3) of the Constitution. Both components must be interrogated.

89 [91]-[92].

90 [106].

91 Mhlanganisweni Community v Minister of Rural Development and Land Reform \& Others [2012] JOL 28899 (LCC) [51]. 


\subsubsection{Compensation in Comparative and International Jurisprudence}

In asserting that market value is the standard for compensation for expropriation, Gildenhuys $\mathrm{J}$ relies on decisions of the Australian High Court ${ }^{92}$ and the English House of Lords. ${ }^{93}$ While this is not stated explicitly, he appears to believe that these decisions are demonstrative of a universally accepted approach to compensation in comparative and international law.

In an important consideration of scholarly work and jurisprudence around compensation from expropriation in South Africa, Zimmerman provocatively asserts that South African work on compensation over-emphasizes the universality of market value in international and comparative expropriation jurisprudence. ${ }^{94}$ To problematize the assumption that market value is the universal standard, she notes the judgment of the European Court of Human Rights in James $v U K .{ }^{95}$ In the James case, the Court considered whether compensation for an expropriation need be calculated according to market value to accord with the European Convention on Human Rights right to property entrenched in Article 1 of Protocol $1 .{ }^{96}$ The Court states clearly that where public interest factors such as advancing social justice underpin an expropriation, compensation at less than market value may be permissible. ${ }^{97}$

That compensation is not universally equated to market value accords with the Constitutional Court's findings in Certification of the Constitution of the Republic of South Africa, $1996 .{ }^{98}$ The Court was asked to find that the provisions of section 25(3) fall short of the "universally accepted" standard that the payment of compensation should be calculated on the basis of market value. ${ }^{99}$ The Court refused to do so, finding that "[a]n examination of international conventions and foreign constitutions suggests that a wide range of criteria for expropriation and the payment of compensation exists." 100

92 Nelungaloo Pty Ltd v Commonwealth (1948) 75 CLR 495571.

93 Birmingham City Corporation v West Midland Baptist (Trust) Association (Incorporated) [1970] AC 874.

94 Jill Zimmerman, Property on the Line: Is an Expropriation-Centred Land Reform Constitutionally Permissible?, South African Law Journal, volume 122, 2005, 398.

9598 Eur Ct HR (ser A) (1986).

96 [54]; Council of Europe, European Convention for the Protection of Human Rights and Fundamental Freedoms, as amended by Protocols Nos. 11 and 14, http://www.refworld.org/docid/3ae6 b3b04.html (accessed 18 May 2014). Article 1 reads as follows: "Every natural or legal person is entitled to the peaceful enjoyment of his possessions. No one shall be deprived of his possessions except in the public interest and subject to the conditions provided for by law and by the general principles of international law.".

9798 Eur Ct HR (ser A) (1986) [54].

981996 (4) SA 744 (CC).

99 [73].

$100[73]$. 


\subsubsection{Compensation in South African Law}

Gildenhuys J does not differentiate between the South African and comparative sources that he relies on to substantiate his understanding of the nature of compensation. It seems clear, however, that the conclusions he draws regarding the nature of compensation in South African law are heavily informed by his interpretation of comparative law. It should also be noted that he makes no effort to consider whether the specific terms of section 25(3) accord with or depart from the general nature of compensation.

In understanding Gildenhuys J's conclusion, it is instructive to consider the sources on which he relies. As the court indicates, Southwood begins his analysis by finding that the dictionary definition of compensation links what is given to what is lost. ${ }^{101}$ Gildenhuys $\mathrm{J}$ does not mention, however, that Southwood subsequently asserts that "just and equitable" gives immense discretion to courts. ${ }^{102}$ On this basis, Southwood asserts "there is no warrant in 25(3) for taking the market value of the expropriated property as a starting point in assessing the compensation package." ${ }^{\prime 103} \mathrm{He}$ instead suggests that section 25(3) should be applied by balancing the public interest and the expropriatee's interest in light of the relevant circumstances. ${ }^{104}$

The South African case law that Gildenhuys J cites must also be contextualised. Sandton Town Council v Erf 89 Sandown Extension 2 (Pty) Ltd dealt with a pre-constitutional expropriation. ${ }^{105}$ Expropriation in the pre-constitutional era was expressly based on market value. The Harms judgment in Mphela cited by Gildenhuys, ${ }^{106}$ subsequently upheld by the Constitutional Court, ${ }^{107}$ appears more relevant. It too, however, stands to be distinguished. The judgment considered compensation for a restitution claimant who had established a dispossession under racially discriminatory legislation. ${ }^{108}$ Compensation for claimants necessitates a fundamentally different approach than compensation for current land owners. On the one hand, compensation for claimants seeks to redress past injustices. Mphela held, for instance, that given the impact of the forced relocation compensation for the pre-constitutional dispossession could be greater than the market value of the property. ${ }^{109}$ On the oth-

101 Southwood, note 52, 25.

102 Southwood, note 52, 27-28.

103 Southwood, note 52, 29.

104 Southwood, note 52, 29-30.

105 Sandton Town Council v Erf 89 Sandown Extension 2 (Pty) Ltd 1986 (4) SA 576 (W).

106 Haakdoornbult Boerdery CC \& Others v Mphela \& Others 2007 (5) SA 596 (SCA).

107 Mphela \& Others v Haakdoornbult Boerdery CC \& Others 2008 (4) SA 488 (CC).

108 Haakdoornbult Boerdery CC \& Others v Mphela \& Others 2007 (5) SA 596 (SCA) [3]; while not mentioned in the judgment, it is worth noting that Mphela's approach to the nature of compensation at [48] is informed by Gildenhuys J's statement that "[c]ompensation, to be fair, must recompense" in Baphiring Community v Uys 2007 (5) SA 585 (LCC) [12]. This judgment considered whether the claimants' compensation at the time of dispossession had been acceptable.

109 [47]. 
er hand, compensation for current land owners must be balanced against a public interest that explicitly includes land reform. ${ }^{110}$

This distinction flows from the uniqueness of the South African Constitution's section 25(3) particularly and section 25 as a whole. While Gildenhuys J elides the section's specific language, the section itself first states that compensation must be just and equitable. It then states that compensation should reflect a balance between the public interest (which explicitly includes land reform per section 25(4)) and the interests of those affected (which in land restitution surely includes both land owners and restitution claimants). It is only after this that market value features, and here as only one of five factors in a non-exhaustive list of factors for considering just and equitable compensation.

Indeed, when considering section 25 , the market value of the property is the only factor that aligns with the assertion that compensation entails placing the full money equivalent of the property in the hands of the owner. If the drafters had intended compensation to be synonymous with the full money equivalent this intent surely could have been expressed far more clearly. As Budlender has written: ${ }^{111}$

"[t]he inclusion of market value as one of a number of relevant factors is the clearest possible signal that market value is not necessarily the guideline for the determination of compensation. This is therefore an attempt to avoid the tendency of courts to interpret 'just and equitable' as meaning market value."

As market value is not necessarily the guideline for the determination of compensation, it is necessary to articulate an approach to section 25(3) that does not enshrine it as such a guideline.

\subsubsection{A Purposive Approach to Section 25(3)}

To appreciate the nature of compensation in South Africa law more fully, one must consider the language of section 25(3) in light of comparative law and the objects of the Constitution. Returning to Zimmerman, she extends her criticism of South African academic writing and jurisprudence by noting that in considering comparative law, the Constitutional Court in $S v$ Makwanyane requires "due regard to our legal system, our history and circumstances, and the structure and language of our own Constitution." 112 As the comparative law considered by Gildenhuys J entrenches market value and the comparative law set out by Zimmerman above challenges market value's centrality, it is necessary to consider which sources best accord with South Africa's legal system, history and the language of section 25(3).

110 S 25(3) read with s 25(4) of the Constitution of the Republic of South Africa, 1996; discussed further below.

111 Geoff Budlender, The Constitutional Protection of Property Rights, in Budlender, Latsky \& Roux (eds), Juta's New Land Law, Cape Town 1998, 58.

1121995 (3) SA 391 (CC) 415 D-E. 
Given the Constitution's aim to recognise and undo the divisions of South Africa's past, section 25(3)'s express incorporation of land reform as a factor in determining compensation should be considered seriously in any discussion of compensation for expropriation in South African law. As Zimmerman has argued, section 25 "is designed, in part, to oversee and guide the constitutionally mandated reversal of centuries of racism and economic exploitation." 113 Considering the constitutional imperative for land reform to undo the injustices of the past, the European Court's finding that social justice considerations allow for compensation below the market value is particularly salient. Zimmerman therefore argues for an interpretation of section 25(3) that, while accepting market value is a factor, is clear that its weight should not be overstated. ${ }^{114}$

In response to Zimmerman, Van der Walt does not challenge her problematisation of reliance on market value in comparative and South African law. ${ }^{115}$ Rather, he disputes her assertion that South Africa's academics have actually emphasised the universality of market value. ${ }^{116}$ He notes the important early work of Eisenberg ${ }^{117}$ and Claassens ${ }^{118}$ in asserting that comparative analysis demonstrates that market value be reduced to a subordinate role in a transformative, land reform context. ${ }^{119} \mathrm{He}$ then cites a lengthy list of sources that he argues developed this assertion and all rejected the centrality of market value. ${ }^{120} \mathrm{He}$ argues that South African scholarship is "remarkably unanimous" on this point. ${ }^{121}$

This defence of South African scholars' understanding of comparative jurisprudence around compensation argues that instead of accepting the universality of market value, scholars broadly reject market value's centrality, especially in the land reform context. Van der Walt suggests an explanation for Zimmerman's conclusions to the contrary may be that she "simply did not read the South African literature carefully enough or, having done so, overstated her case." 122

Despite Van der Walt's assessment of the "remarkably unanimous" position of the South African Academy, Gildenhuys J concludes from comparative legal sources that the nature of compensation is to place in the hands of the expropriated owner the full money

113 Zimmerman, note 93, 398-399.

114 Zimmerman, note 93, 411.

115 Andries Van der Walt, Reconciling the State's Duties to Promote Land Reform and to Pay 'just and equitable' Compensation for Expropriation, South African Law Journal, volume 123, 2006, 23.

116 Van der Walt, note 114, 26.

117 Andra Eisenberg, Different Constitutional Formulations of Compensation Clauses, South African Journal of Human Rights volume 9 1993, 412 - 416, 420-1.

118 Aninka Claassens, Compensation for Expropriation: The Political and Economic Parameters of Market Value Compensation, South African Journal of Human Rights volume 9 1993, 422.

119 Van der Walt AJ, note 114, 26.

120 Van der Walt, note 114, 26-7.

121 Van der Walt, note 114, 26.

122 Van der Walt, note 114, 28. 
equivalent of the expropriated property. ${ }^{123}$ Gildenhuys J's failure to engage with a varied comparative jurisprudence, as well as the South African academy, in ascertaining the nature of compensation in South African expropriation law foreshadows a willingness to centralize market value to the detriment of the rest of section 25(3).

Having cited Southwood's dictionary definition of compensation, Gildenhuys J would have done well to consider the whole of Southwood's consideration of compensation in terms of the South African Constitution. Southwood's assessment of "just and equitable" as allowing courts' broad discretion in balancing the interests of land owners, claimants and the public at large seems an accurate interpretation of section 25(3). Rather than a reflection of the nature of compensation, market value should be seen as just one factor in this balancing test.

\subsection{Market Value}

Having established that to compensate requires recompense, Gildenhuys $\mathrm{J}$ moves on to consider the role of market value. Gildenhuys $\mathrm{J}$ notes that other courts have also followed the two-stage approach set out in Du Toit and states that he will do the same without explicit justification. ${ }^{124}$ The failure to justify the decision to follow the approach adopted in Du Toit is puzzling given the different context in which that decision was made. In Du Toit, the Court considered an expropriation made in terms of section 12 of the Expropriation Act. ${ }^{125}$ A pre-constitutional relic that seems set for revision, ${ }^{126}$ the Act provides for compensation to reflect either the market value of the property (s 12(1)(a)) or the actual financial loss resultant from the expropriation (s 12(1)(b). ${ }^{127}$ The dispute in the case was whether the compensation should be based on the market value (the landowner's position) or the actual financial loss (the state's position). ${ }^{128}$ As both parties framed their arguments in terms of the Expropriation Act, the Court understandably found that the first stage of its approach would be to consider what was payable under the Act based on market value. ${ }^{129}$ After this, the judgment considered whether this outcome was in accordance with the other factors in section 25(3). ${ }^{130}$

123 Mhlanganisweni Community v Minister of Rural Development and Land Reform \& Others [2012] JOL 28899 (LCC) [51].

124 Mhlanganisweni Community v Minister of Rural Development and Land Reform \& Others [2012] JOL 28899 (LCC) [53].

125 Du Toit v Minister of Transport 2006 (1) SA 297 (CC) [1].

126 Department of Public Works, Memorandum on the Objects of the Draft Expropriation Bill, 2015, http://www.publicworks.gov.za/PDFs/documents/WhitePapers/Memorandum_on_Objects_Expro priation_Bill2015_OCSLA.pdf (accessed 15 February 2015).

127 Expropriation Act 54 of 1976.

128 Du Toit $v$ Minister of Transport 2006 (1) SA 297 (CC) [3]-[5].

129 [35].

130 [35]. 
It may be noted that the Constitutional Court in Du Toit cites with approval Gildenhuys J's application of the two-stage approach in the restitution case of Ex Parte Former Highlands: In Re Ash \& Others $v$ Department of Land Affairs. ${ }^{131}$ As with Mphela above, Ex Parte Former Highlands can and should be distinguished as it considered compensation for restitution claimants rather than land owners. Two of the other cases that Gildenhuys J mentions, Abrams $v$ Allie NO \& Others ${ }^{132}$ and Mphela \& Others $v$ Engelbrech \& Others, ${ }^{133}$ also applied the two stage test to consider compensation paid in dispossessions. The final case cited by Gildenhuys J as applying the two-stage test, Khumalo \& Others $v$ Potgieter \& Others, ${ }^{134}$ did involve a land reform claim under the Land Reform (Labour Tenants) Act ${ }^{135}$ but considered compensation for a land owner who purchased the land in 1996. ${ }^{136}$

The contexts in which $D u$ Toit and the other cases applied the two-stage test differ markedly from that of MalaMala, in which compensation was considered in terms of the Restitution Act and where the state and the claimants sought to challenge the centrality of market value in compensation for expropriations. Gildenhuys J's unjustified adoption of the Du Toit approach appears to be precisely what Langa CJ foresaw and sought to avoid in his dissent in $\mathrm{Du}$ Toit. He argued that the two-stage approach is not permitted by the Constitution, asserting that the Constitution expressly avoided the market value-based approach of the Expropriation Act. ${ }^{137} \mathrm{He}$ further argued that the Constitution insists on a different approach founded upon justice and equity. ${ }^{138}$ To Langa CJ, the two-stage approach ensures that market value will continue to be privileged over the other considerations relevant to justice and equity advocated by the Constitution. ${ }^{139}$

The prominent position of land reform in section 25 is an important consideration in ensuring that justice and equity are paramount. In the words of Van der Walt: ${ }^{140}$

"It is clear from the structure and tone of the provision that the calculation of the amount of compensation requires a contextualised judgment with due regard for individual property interests and for the history of land rights in the pre-constitutional era, the new constitutional framework and the legitimate land reform efforts of the state."

131 [2000] 2 All SA 26 LCC [35].

1322004 (4) SA 534 (SCA).

133 [2005] 2 All SA 135 (LCC).

134 [2000] 2 All SA 456 (LCC).

1353 of 1996.

136 [2000] 2 All SA 456 (LCC) [13].

137 Du Toit v Minister of Transport 2006 (1) SA 297 (CC) [84].

138 [84].

139 [84].

140 Van der Walt, note 27, 509. 
Flowing directly from Gildenhuys J's finding that the nature of compensation is the full money equivalent of an expropriated property, the adoption of the two-stage approach frames the ultimate conclusions around compensation by privileging market value. Given this starting position, it is not surprising that Gildenhuys $\mathrm{J}$ found that none of "the other relevant circumstances" had any impact on the calculation of compensation. ${ }^{141}$

\section{3 "The Other Relevant Circumstances"}

Even if the two-stage approach's privileging of market value is accepted, Gildenhuys J's consideration of the whole of section 25(3) outside of market value seems to undervalue the significance of the section 25(3) factors of the history of acquisition and use and the purpose of the expropriation.

\subsubsection{History of Acquisition and Use}

Gildenhuys J's consideration of the history of acquisition and use factor reduces this factor to a narrow approach of considering whether the land owners were directly responsible for racially discriminatory dispossessions. ${ }^{142}$ This contrasts starkly with Van der Walt's statement above that it is clear from section 25(3) that the calculation of compensation requires the consideration of the history of land rights in the pre-constitutional era as a whole. ${ }^{143}$ This narrow approach also fails to give effect to the Constitutional Court's exhortation to consider the "grid of discriminatory laws and practices" in land restitution claims. ${ }^{144}$ In that case, it was said that the Supreme Court of Appeal's narrow approach to identifying relevant racially discriminatory legislation "fall[s] short of recognising the full range of the racist legislative scheme, policies and practices on land from 1913 to 1970 and their disastrous impact on the rights in land of black people."145

Such a narrow approach was anticipated by Zimmerman. She suggested that consideration of the history of the acquisition might be approached without reference to the broader context of colonization and apartheid. ${ }^{146}$ The effect of this approach, to her, is the emphasis of individual land owners' rights over the rights of historically disadvantaged persons and communities without access to land or livelihood. ${ }^{147}$

141 Mhlanganisweni Community v Minister of Rural Development and Land Reform \& Others [2012] JOL 28899 (LCC) [77].

142 [68].

143 Van der Walt, note 27, 509.

144 Department of Land Affairs and Others v Goedgelegen Tropical Fruits (Pty) Ltd 2007 (6) SA 199 (CC) [56].

145 [56].

146 Zimmerman, note 93, 409.

147 Zimmerman, note 93, 409. 
Gildenhuys J's finding that a consideration of the history of acquisition relates only to a land owner's direct participation in an unjust removal lends itself naturally to his concern that wealthy land owners risk being discriminated against unfairly. Considering history of acquisition within the context of a grid of racially discriminatory laws, however, necessitates a different approach. This approach is considered together with the purpose of expropriation factor in the next section.

\subsection{2 "The Purpose of the Expropriation"}

Given that Gildenhuys $\mathrm{J}$ ignores the varied historical factors that lead to the inclusion of land reform in the property clause, it is only natural that he would find considering land reform as a factor that can reduce compensation payable illogical. ${ }^{148}$ The logical reason why a land owner would receive less compensation for a land reform-related expropriation is this: racially discriminatory laws did not operate merely to disadvantage an unfortunate population group. They necessarily operated to the relative advantage of another population group. Land owner's property rights historically flowed directly from a network of legislation and policy designed to benefit these land owners to the detriment of those who are now potential land reform beneficiaries (or their families). ${ }^{149}$ As Bundy has illustrated in more concrete terms: ${ }^{150}$

"An entire history of colonial conquest and dispossession, of cheap labour and systematic exploitation, and of segregation, apartheid and white supremacy has created a society in which 60000 capitalist farmers own 12 times as much land as over 14 million rural poor...this entire edifice is buttressed by law - by statutes, regulations, circulars and government gazettes."

Land reform seeks to remedy this historically orchestrated disjuncture. ${ }^{151}$ If the history of land law benefitting land owners is ignored in considering the history of acquisition and use factor, as it is by Gildenhuys $\mathrm{J}$ above, the logic of considering land reform as a purpose of expropriation factor in determining compensation also falls away.

In considering Gildenhuys J's elision of the constitutional importance of land reform in the application of the purpose of expropriation factor, it is again helpful to consider the sources on which he relies. Gildenhuys J's reliance on Van der Walt is puzzling. ${ }^{152}$ Van der Walt's finding that land reform should not override other factors is made at the end of a

148 Mhlanganisweni Community v Minister of Rural Development and Land Reform \& Others [2012] JOL 28899 (LCC) [72].

149 Claassens, note 117, 422-423.

150 Bundy, note 1, 11.

151 Alexkor Ltd and Another v Richtersveld Community and Others [2003] ZACC 18; 2004 (5) SA 460 (CC) [98].

152 Mhlanganisweni Community v Minister of Rural Development and Land Reform \& Others [2012] JOL 28899 (LCC) [72]. 
paragraph which considers whether the mere fact that an expropriation is effected for the purposes of land reform will justify the absence of any compensation at all. ${ }^{153}$ In finding that land reform alone cannot justify the absence of compensation, Van der Walt argues that determining compensation on the basis of only one section 25(3) factor, be it land reform or market value, is not permissible. ${ }^{154}$ This assertion simply cannot be relied upon, as Gildenhuys $\mathrm{J}$ appears to do, ${ }^{155}$ to find that the purpose of land reform has no bearing on the compensation payable in an expropriation.

Moving on, it is unclear why Gildenhuys J cites Van der Walt's assertion regarding land reform's worldwide acceptance in arguing that land reform should not be a factor in the compensation calculation. ${ }^{156}$ Before considering the context in which Van der Walt made this assertion, some assessment of Gildenhuys J's position is in order. It should be noted that Gildenhuys $\mathrm{J}$ does not expressly argue that land reform should not lead to a reduction in compensation payable. He rather argues that it is illogical to elevate land reform above other forms of public interest expropriations such as expropriations for building hospitals and schools. ${ }^{157}$ The essence of his point appears to be as follows: other public interest factors do not enable the detraction from market value under purpose of expropriation. Why should land reform be treated differently?

Seen from this angle, the question is salient. The short answer is that the non-land reform expropriations are effected in terms of the Expropriation Act. The Act, while necessarily applied together with the Constitution, only considers market value. In contrast, the Restitution Act provides that expropriations for land restitution are to be effected in terms of section 25(3) as a whole. An expropriation that is effected entirely in terms of land restitution can therefore logically be differentiated from an expropriation in terms of the Expropriation Act.

The longer answer is that Gildenhuys $\mathrm{J}$ is correct - land reform need not be treated differently from other legitimate purposes for expropriation. This answer necessitates considering section 25(3) as a whole. As argued above, Gildenhuys J's approach to the nature of compensation has no regard for the unique language of section 25(3). To equate compensation with market value is to elevate the rights of the land owner before the section 25(3) factors are even applied.

He is misdirected in doing so. The true nature of compensation in section 25(3) is a balancing act between the public interest and the interests of those affected, with wide discretion to consider factors to reach a just and equitable amount. The special place of land reform in the Constitution is not that it ranks superior to other legitimate purposes for expro-

153 Van der Walt, note 27, 506-507.

154 Van der Walt, note 27, 506.

155 Mhlanganisweni Community v Minister of Rural Development and Land Reform \& Others [2012] JOL 28899 (LCC) [72].

156 [73].

$157[73]$. 
priations. The purpose for expropriation factor should be applicable in every expropriation. Should an expropriation be made to build a hospital or a school, this purpose will be a factor in determining compensation. In the exercise of discretion, a just and equitable valuation may even give greater weight to building a hospital than it might have for an expropriation for the purpose of land reform.

Instead of superiority, the special place of land reform in the Constitution is rather that it will always be accepted as being in the public interest. ${ }^{158}$ This assertion rests not only on section 25(8), which Gildenhuys J considered, but also on section 25(4)(a). The section states that for purposes of the section, "the public interest includes the nation's commitment to land reform." It also rests on the constitutional imperative to recognise the injustices of the past and seek to heal the divisions engendered by these injustices through social justice and fundamental human rights. ${ }^{159}$ Other purposes for expropriation must be established as being in the public interest to rank as factors in the calculation of compensation. An expropriation for the purposes of land reform is assumed to be in the public interest. To establish this, of course, does not mean that the other factors fall away. Van der Walt's assertion that the purpose of land reform does not override the other factors in section 25(3) is accepted. ${ }^{160}$ Land reform, however, must be considered be considered together with the other factors in reaching a just and equitable determination of compensation.

Returning to Gildenhuys J's reliance on Van der Walt's assertion regarding the worldwide acceptance of land reform, it is perhaps fitting to conclude this section with the full quote: ${ }^{161}$

"In fact, it is accepted worldwide that land reform is a legitimate part of the state's duties to be undertaken in the public interest, and also that the protection of property has to be seen as part of a process of establishing an equitable constitutional balance between the interests of individuals and the public interest. What really impedes the process of land reform is much rather a traditional, private-law perception of property as a fundamentally unrestrictable and inviolate right: if this perception of property is accepted in the constitutional sphere, the constitutional property clause is mistakenly seen as entrenching or insulating existing rights from all change or interference."

Given the state's desire to move away from willing buyer-willing seller, the question of whether the constitutional property clause essentially entrenches a fundamentally inviolable right is apposite. The MalaMala judgment's elevation of existing rights in establishing the nature of compensation and its erasure of the full extent of South Africa's history of land ownership in its application of the section 25(3) factors treads close to such an entrench-

158 Provided, of course, that the land reform purpose asserted for the expropriation is genuine.

159 Preamble of the Constitution of the Republic of South Africa, 1996.

160 Van der Walt, note 27, 506-507.

161 Van der Walt, note 27,162-163. 
ment. As has been argued, this is to the benefit of those who benefited from apartheid and therefore have existing property rights. It is to the detriment of those who do not have rights over property because the grid of discriminatory legislation, policy and practice expressly prevented them from obtaining those rights.

This leads to the following questions: will the judgment serve as an impediment to the new land reform model? What impact will it have on the application of the Property Valuation Act's section 25(3)-based test for compensation?

\section{Conclusion: Implications of MalaMala for the Property Valuation Act}

The judgment's interpretation of section 25(3)'s provisions for calculating compensation challenges the assumption that the Property Valuation Act's implementation will de-emphasise market value's significance. On closer scrutiny, however, Gildenhuys J's interpretation of section 25(3) should not restrict policy-makers. His articulation of the nature of compensation is under-developed and undercut by some of his own sources. The application of the "other" factors in section 25(3) is under-emphasised accordingly.

In fact, the Property Valuation Act may have come at an ideal time. In terms of section 20(1) of the Act, the "Minister may make regulations with regard to: (b) The criteria, procedures and guidelines for the valuation of property in terms of this Act." With the appeal against the MalaMala judgment shelved after a settlement agreement with the land owners, ${ }^{162}$ it may be some time before its approach is challenged in court. In the meantime, land claims settlement negotiations and Land Claims Court litigation will be informed by Gildenhuys J's emphasis on market value. In this context, clear regulations from the Minister detailing a more holistic approach to valuation may be the most effective means of shifting the approach to section 25(3). While their application will be challenged in court, if the regulations reflect the broader sense of "just and equitable" compensation courts may find it more difficult to defend the status quo.

Returning for the last time to Zimmerman, her proposed alternative approach may be particularly apt in this moment. Her proposal to impose a standardised discount for expropriations for land reform is well worth re-visiting in formulating the regulations that will guide the Valuer-General. ${ }^{163}$ While Van der Walt expresses concerns that this might entail excessive reliance on a single section $25(3)$ factor, ${ }^{164}$ he does accept that a general land reform discount could be set out for land reform provided it allowed for sufficient judicial discretion. ${ }^{165}$

162 MalaMala Game Reserve, Urgent press release regarding the sale of MalaMala Game Reserve, November 2013, http://www.malamala.com/Communications/MM_Land-Claim-update_Jan14/M M_Land-claim_Update_2014.html (accessed 15 February 2015).

163 Zimmerman, note 93, 408.

164 Van der Walt, note 114, 38.

165 Van der Walt, note 114, 39-40. 
The time is ripe for such a discount. In developing the regulations, there should also be consideration of the "historic cost of acquisition model" advanced by the applicants" in MalaMala. As the model begins with the amount paid at acquisition and calculates it forward using pre-determined investment indices, ${ }^{166}$ it inherently captures distortions in the land market at the time of the purchase.

In light of the Constitutional Court's recent judgment in Florence $v$ Government of the Republic of South Africa, ${ }^{167}$ it is possible that the Consumer Price Index (CPI) could serve as this index. That case considered the current approach to compensating restitution claimants when the restoration of their land is found to be infeasible. ${ }^{168}$ This calculation entails determining the value of their property at the time of the dispossession and adjusting it by CPI. The claimants argued that compensation in terms of CPI does not place the claimants in the same position they would have been in "if the land had not been taken."169 This seems an uncontroversial position. Property values in South Africa have increased at a faster rate than CPI. If the land had not been taken the claimants would have an asset worth far more than the value of the property at the time of the dispossession calculated forward by CPI.

In rejecting these contentions, the court held that the purpose of compensation in lieu of restitution was to restore claimants "to a position as if they had been adequately compensated immediately after the dispossession." "I70 In the court's view, to find otherwise over-emphasize market value and would likely "result in over-compensation of claimants, an outcome which is at odds with the purpose of the Restitution Act." 171

If it is fair that land restitution claimants are to be awarded the market value of their land at the time of the dispossession calculated forward by CPI, a similar approach should be considered for compensating land buyers. Compensating land owners with the amount paid at the time they purchased the land would remove the benefit received by purchasing land in a distorted market and having its value appreciate with the removal of those distortions. If this position is accepted, it would be unjust to use an index other than CPI for land owners when that is the approved indicator for restitution claimants.

In line with Van der Walt's caution above, this approach should also allow for discretion in adjusting the compensation based on the specific facts of the expropriation.

Regardless of the approach adopted, the Property Valuation Act's implementation should not be impeded by the judgment in the MalaMala case. In fact, the Act is an important opportunity to reformulate the approach to compensation for expropriations. This new

166 Mhlanganisweni Community v Minister of Rural Development and Land Reform \& Others [2012] JOL 28899 (LCC) [61], [63].

1672014 (6) SA 456 (CC).

168 [38].

169 [39].

170 [132].

171 [142]. 
approach should conceive of the nature of compensation as being based on broad judicial discretion considering each of the section 25(3) factors in reaching an equitable outcome. In this discretion, the history of acquisition factor should not be subject to a narrow approach that only considers whether there was direct involvement by the land owners in a dispossession. It must factor in how current land owners benefitted from the grid of laws and policies that advanced white ownership. While this discretion need not position land reform as more important than other public interest factors, it should ensure that where an expropriation is made for the purposes of land reform this is always considered as a factor in determining compensation. 